\title{
ANALISIS GENDER DALAM UPAYA ADAPTASI DAN MITIGASI PERUBAHAN IKLIM RUMAH TANGGA PERTANIAN
}

\section{Analysis Gender in The Adaptation and Mitigation Acts to Climate Change by Farm Households}

\author{
Fadhilla Putri Ramadhani ${ }^{1)}$ dan Aida Vitayala S Hubeis ${ }^{2)}$ \\ ${ }^{1)}$ Departemen Sains Komunikasi dan Pengembangan Masyarakat, Fakultas Ekologi Manusia, \\ IPB University, Dramaga, Bogor 16680, Indonesia \\ E-mail: dhillarama@gmail.com, aidahubeis@apps.ipb.ac.id
}

\begin{abstract}
Gekbrong Village is the only village in West Java designated as a pilot village in adaptation and mitigation of climate change programme called 'Program kampung Iklim' by the Ministry of Environment and Forestry in 2013. Adaptation and mitigation to climate change is not gender-neutral as women and men have the capacity, role, and contribution in adaptation and mitigation to climate change differently. However, gender bias in the activities leads to an imbalance in the capacity of adaptation and mitigation across gender to deal with climate change effects. The overall objective of the study was to analyze the role of gender in agricultural households, and to analyze the relationship between gender roles in agricultural households with gender equality in adaptation and mitigation of climate change in agricultural households. This research uses quantitative data by survey method by using simple random sampling technique analyzed by cross tabulation and Rank Spearman supported by qualitative data with in-depth interview.
\end{abstract}

Keywords : climate change, gender role, Program Kampung Iklim

\begin{abstract}
ABSTRAK
Desa Gekbrong merupakan satu-satunya desa di Jawa Barat yang ditunjuk sebagai desa percontohan dalam kegiatan upaya adaptasi dan mitigasi perubahan iklim pada Program Kampung Iklim oleh Kementerian Lingkungan Hidup dan Kehutanan di tahun 2013. Pada dasarnya, adaptasi dan mitigasi perubahan iklim tidak netral gender karena perempuan dan laki-laki memiliki kapasitas, peran, dan berkontribusi secara berbeda. Namun adanya bias gender dalam penerapannya, upaya adaptasi dan mitigasi perubahan iklim menimbulkan ketidakadilan, salah satunya beban kerja ganda pada perempuan. Tujuan dari penelitian ini yaitu untuk menganalisis hubungan antara karakteristik dan pembagian peran gender dalam rumah tangga pertanian dengan tingkat kesetaraan gender dalam upaya adaptasi dan mitigasi perubahan iklim. Penelitian ini menggunakan data kuantitatif metode survey, diolah dengan menggunakan teknik simple random sampling, dianalisis menggunakan tabulasi silang dan Rank Spearman, serta didukung data kualitatif dengan wawancara mendalam.
\end{abstract}

Kata Kunci : peran gender, perubahan iklim, Program Kampung Iklim

\section{PENDAHULUAN}

Perubahan iklim merupakan salah satu ancaman yang sangat serius terhadap sektor pertanian dan potensial mendatangkan masalah baru bagi keberlanjutan produksi pangan (Badan Penelitian dan Pengembangan Pertanian Kementerian Pertanian 2011). Perubahan iklim adalah kondisi beberapa unsur iklim yang intensitasnya cenderung berubah atau menyimpang dari dinamika dan kondisi rata-rata menuju ke arah tertentu (meningkat atau menurun). Selain meningkatkan suhu bumi, perubahan iklim juga menyebabkan meningkatnya frekuensi kejadian anomali iklim, pergeseran dan ketidaktentuan curah hujan dan musim serta meningkatnya permukaan air laut (Las et al 2011). Pertanian tanaman pangan dan hortikultura merupakan sub sektor yang paling rentan terhadap perubahan pola curah hujan karena tanaman hortikultura umumnya merupakan tanaman semusim yang relatif sensitif terhadap kelebihan dan kekurangan air. Secara teknis, kerentanan tanaman hortikultura sangat berhubungan dengan sistem penggunaan lahan, sifat tanah, pola tanam, teknologi pengelolaan tanah, air, tanaman, dan varietas.

Pada dasarnya, petani akan bertindak reaktif dan melakukan antisipasi terhadap dampak yang terjadi 
akibat dari perubahan iklim, dengan direncanakan atau dilakukan spontan (Kurniawati 2012). Tindakan spontan tidak dilakukan dengan kesadaran dalam memrediksi perubahan iklim, namun berdasarkan pengalaman dan kondisi yang berlaku. Seperti yang dilakukan petani cabai di Kediri dalam penelitian Maulidah et al (2012), perubahan iklim yang ditandai dengan hujan turun sepanjang tahun 2010 membuat beberapa petani menambah perlakuan atau perawatan pada tanaman cabai rawit di lahan. Perlakuan tersebut antara lain: penyulaman tanaman, penambahan frekuensi penyemprotan pupuk daun, lebih kerap melakukan penyiangan dan pengguludan, dan memperbaiki drainase lahan. Perlakuan-perlakuan tersebut membuat petani cabai di Kediri mampu memertahankan kondisi tanaman cabai rawitnya, meski hanya dengan tindakan spontan berdasarkan pengalaman.

Badan Penelitian dan Pengembangan Pertanian, Irianto (2004) dalam surat kabar Kompas menyatakan bahwa meskipun bukan sebagai kepala rumah tangga, perempuan merupakan penerima dampak terbesar sekaligus makhluk yang harus melakukan pencegahan (mitigasi) dan adaptasi. Saat terjadi perubahan iklim ekstrem dalam bentuk kekeringan dahsyat yang berdampak terhadap penurunan curah hujan di musim hujan dan musim kemarau, lamanya musim kemarau dan menurunnya ketersediaan air untuk pertanian dan domestik, perempuanlah yang pertama kali terpaksa harus melakukan adaptasi dengan mengambil air untuk memenuhi keperluan minum dari sumber air yang letaknya sangat jauh dengan akses yang sangat terbatas. Membicarakan persoalan gender berarti membahas persoalan relasi sosial yang dipertautkan dengan pembagian kerja dan tanggung jawab antara perempuan dan laki-laki (Hubeis 2010). Begitu juga dalam menanggulangi perubahan iklim, laki-laki dan perempuan memiliki peran berbeda dalam mitigasi dan adaptasi terhadap perubahan iklim karena adanya perbedaan peran nyata dalam strategi mencari penghasilan dan rumahtangga (UNDP diacu oleh KPPPA 2011).

Upaya adaptasi perubahan iklim juga dilakukan oleh petani hortikultura di Desa Gekbrong, Kecamatan Gekbrong, Kabupaten Cianjur. Pada tahun 2012 Desa Gekbrong dilanda banjir besar yang menghanyutkan tiga siswi SMP Gekbrong yang tinggal di Desa Gekbrong. Selain itu, berdasarkan laporan verifikasi oleh KLHK (2013), Desa Gekbrong mengalami tanah longsor pada tahun 2007. Untuk mengantisipasi hal tersebut, petani di
Desa Gekbrong secara inisiatif melakukan gerakan adaptasi dan mitigasi perubahan iklim. Hingga pada tahun 2013, Desa gekbrong merupakan satu-satunya desa di Jawa Barat yang mendapatkan sertifikat dan trophy sebagai desa percontohan Program Kampung Iklim oleh Kementerian Lingkungan Hidup dan Kehutanan. Seperti program pembangunan lainnya, dimana pengarusutamaan gender (PUG) menjadi salah satu landasan, begitu pun dengan Program Kampung Iklim. Berdasarkan Peraturan Menteri Lingkungan Hidup Nomor 19 Tahun 2012 tentang Program Kampung Iklim, yang kemudian diperbaharui pada Peraturan Menteri Lingkungan Hidup dan Kehutanan Republik Indonesia Nomor P.84/MENLHK-SETJEN/KUM.1/11/2016, salah satu fokus dari Program Kampung Iklim yaitu diterapkannya pengarusutamaan gender dalam pelaksanaan kegiatan adaptasi dan mitigasi perubahan iklim.

Permasalahannya, sebagian besar diantara kita pada masa lalu dan mungkin juga masih berlanjut hingga kini, menjadikan perbedaan biologis antara laki-Iaki dan perempuan sebagai suatu pembenaran diskriminasi terhadap perempuan (Mugniesyah 2007). Adanya relasi sosial yang bias gender, pada akhirnya berdampak pada minimnya akses perempuan terhadap sumberdaya, baik sumberdaya alam, sumberdaya ekonomi, maupun sumberdaya politik (Rusmadi 2016). Akibatnya, pada saat terpapar dampak perubahan iklim, perempuan menjadi kelompok yang memiliki beban ganda, lebih banyak menjadi korban, dan menjadi kelompok yang lebih rentan. Hal ini dikarenakan dampak perubahan iklim dapat menyulitkan ekonomi rumah tangga, maka perempuan turut membantu suami untuk memperoleh pendapatan tambahan dan tetap melaksanakan tugas-tugas domestiknya.

Berdasarkan latar belakang tersebut, menjadi penting untuk penulis meneliti pelaksanaan kegiatan upaya adaptasi dan mitigasi perubahan iklim pada rumah tangga pertanian berdasarkan perspektif gender untuk mendapat gambaran pencapaian kesetaraan dan keadilan gender dalam kegiatan upaya adaptasi dan mitigasi perubahan iklim rumah tangga pertanian di Desa Gekbrong.

Penelitian yang dilakukan oleh Findeis dan Swaminathan (2002), saat suami pada rumah tangga pertanian tak bekerja di luar sektor pertanian dan terikat seluruh waktunya untuk usahatani, maka terjadi kecenderungan wanita tani mencari kegiatan lain. Begitu pula pada pengambilan keputusan 
usahatani terbukti berhubungan erat dengan karakteristik rumah tangga petani. Peran gender menurut Hubeis (2010), menampilkan kesepakatan pandangan dalam masyarakat dan budaya tertentu perihal ketepatan dan kelaziman bertindak untuk seks tertentu (jenis kelamin tertentu) dan masyarakat tertentu. Sehubungan dengan hal itu, penting bagi peneliti untuk mengidentifikasi bagaimana karakteristik rumah tangga dan pembagian peran gender dalam rumah tangga pertanian di Desa Gekbrong, serta hubungan antar keduanya?

McCright (2010) berpendapat bahwa perempuan underestimate dalam pengetahuan perubahan iklim daripada laki-laki, namun sebenarnya perempuan memiliki kesadaran yang lebih besar terhadap perubahan iklim dibanding laki-laki. Perbedaan gender sesungguhnya tidak menjadi masalah sepanjang tidak melahirkan ketidakadilan gender (gender inequalities), yang menjadi persoalan ternyata perbedaan gender telah melahirkan ketidakadilan, baik bagi kaum laki-laki maupun terutama pada kaum perempuan. Sehubungan dengan itu perlu dikaji bagaimana tingkat kesetaraan gender dalam kegiatan upaya adaptasi dan mitigasi perubahan iklim rumah tangga pertanian di Desa Gekbrong?

Kesetaraaan gender berkaitan erat dengan karakteristik sosial dan ekonomi rumah tangga. Kondisi perekonomian yang rendah akan memiliki keterkaitan dengan kemampuan akses, kontrol, partisipasi dan manfaat. Hal tersebut sejalan dengan penelitian yang dilakukan oleh Yuwono (2012) yang menyatakan bahwa karakteristik sosial ekonomi rumah tangga memiliki hubungan yang nyata dan signifikan dengan kemampuan mengakses dan mengontrol sumber daya. Menurut KPPPA (2015) adaptasi perubahan iklim tidak netral gender karena perempuan dan laki-laki memiliki kapasitas, peran, dan berkontribusi terhadap adaptasi perubahan iklim secara berbeda. Perempuan dan laki-laki juga memiliki perbedaan kebutuhan (strategi maupun praktis) dan minat dalam upaya-upaya beradaptasi. Hal tersebut menjadi penting untuk dikaji bagaimana hubungan antara karakteristik dan pembagian peran gender dalam rumah tangga dengan tingkat kesetaraan gender dalam kegiatan upaya adaptasi dan mitigasi perubahan iklim rumah tangga pertanian di Desa Gekbrong?

\section{PENDEKATAN TEORITIS}

\section{Konsep Gender}

Konsep gender menurut Fakih (1999) adalah suatu sifat yang melekat pada kaum laki-laki dan perempuan yang dikonstruksikan secara sosial maupun kultural. Perlu untuk disadari bahwa konsep gender berbeda dari seks (jenis kelamin). Seks (jenis kelamin) merupakan penafsiran atau pembagian dua jenis kelamin manusia yang ditentukan secara biologis sejak lahir. Misalnya bahwa manusia yang berjenis kelamin laki-laki adalah manusia yang memiliki penis, memiliki jakala, dan memproduksi sperma, sedangkan manusia berjenis kelamin perempuan adalah manusia yang memiliki alat reproduksi rahim, vagina dan alat menyusui. Sedangkan konsep gender adalah semua hal yang dapat dipertukarkan antara sifat perempuan dan lakilaki, yang bisa berubah dari waktu ke waktu serta berbeda dari tempat ke tempat lainnya, maupun berbeda dari suatu kelas ke kelas lainnya (Fakih 1999). Fakih (1999) dan Hubeis (2010) menjelaskan adanya 3 (tiga) kategori peranan gender yaitu:

\begin{tabular}{llll}
\multicolumn{3}{l}{ Tabel 1 Klasifikasi peran gender } \\
\hline Gender & Reproduktif & Produktif & Sosial \\
\hline Perem- & Peran & Acap & Manajemen, jasa \\
puan & utama: Istri, & diasumsi- & penyuluhan, \\
& ibu, ibu & kan tidak & terkait pada aspek \\
& rumah & memiliki & peran reproduktif \\
& tangga & peran & pekerja tidak \\
& (keluarga) & produktif & dibayar \\
& & pembantu & (informal) \\
& & (turut) & \\
& & mencari & \\
& & nafkah & \\
& & keluarga. & \\
\hline Laki- & Bapak & Peran utama: & Kepemimpin-an, \\
laki & kepala & mencari & politik, \\
& rumah & nafkah & ketahanan/mi- \\
& tangga. & keluarga. & liter, pekerja \\
& & & dibayar \\
\hline
\end{tabular}

Sumber: Hubeis (2010)

Terdapat dua kelompok atau golongan yang mendefinisikan gender secara berbeda. Kelompok yang pertama adalah sekelompok feminis yang mengatakan bahwa perbedaan jenis kelamin tidak menyebabkan perbedaan peran dan perilaku gender dalam tataran sosial. Kelompok kedua menganggap bahwa perbedaan jenis kelamin akan menyebabkan perbedaan perlakuan atau peran berdasarkan gender (Megawangi dalam Puspitawati 2010). 


\section{Teknik Analisis Gender}

Menurut Puspitawati (2008) analisis gender merupakan suatu metode atau alat untuk mendeteksi kesenjangan melalui penyediaan data dan fakta serta informasi tentang gender yaitu data yang terpilah antara laki-laki dan perempuan dalam aspek akses, peran, kontrol dan manfaat. Sehingga analisis gender adalah proses menganalisis data dan informasi secara sistematis tentang laki-laki dan perempuan untuk mengidentifikasi dan mengungkapkan kedudukan, fungsi, peran dan tanggung jawab laki-laki dan perempuan, serta faktor-faktor yang mempengaruhi.

BAPPENAS (2007) dalam perencanaan pembangunan dan perancangan program terlebih dahulu dilakukan analisis kesenjangan gender dengan menggunakan Gender Analysis Pathway

(GAP). Dari lensa GAP, terdapat empat faktor yaitu, akses, manfaat, partisipasi dan penguasaan (kontrol) yang berpotensi menimbulkan kesenjangan antara perempuan dan laki-laki baik sebagai obyek maupun sebagai subyek pembangunan, yaitu:

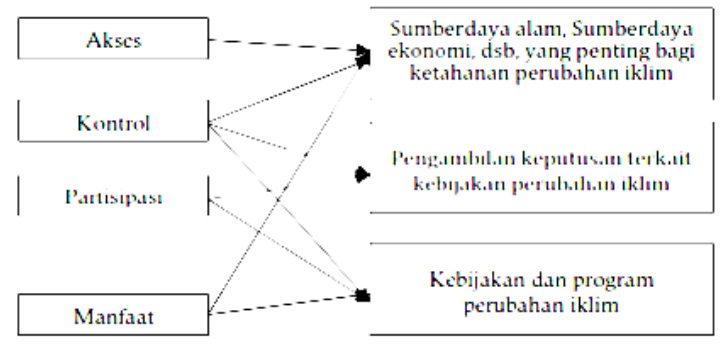

Gambar 1 Implementasi pengarusutamaan gender

1. Akses. Memperhitungkan kemungkinan memberlakukan cara yang berbeda bagi perempuan dan laki-laki dalam memperoleh akses (yang sama).

2. Kontrol. Perencanaan kebijakan program kegiatan pembangunan harus memberikan kontrol (penguasaan) yang setara terhadap sumber-sumber daya pembangunan (informasi, pengetahuan, kredit, dan sumber daya lainnya) bagi perempuan dan laki-laki.

3. Partisipasi. Keikutsertaan atau suara masyarakat baik kelompok perempuan atau laki-laki (dalam hal aspirasi, pengalaman, kebutuhan) dipertimbangkan dan terakomodasi dalam proses perencanaan pembangunan.

4. Manfaat. Apa yang dianggap bermanfaat bagi laki-laki, belum tentu dianggap bermanfaat bagi perempuan. Demkian pula sebaliknya. Oleh sebab itu kebutuhan serta aspirasi keduanya harus dipertimbangkan.

\section{Kesetaraan dan Keadilan Gender}

Perbedaan gender sesungguhnya tidak menjadi masalah sepanjang tidakmelahirkan ketidakadilan gender (gender inequalities). Ketidakadilan gender merupakan sistem dan struktur dimana baik laki-laki maupun perempuan menjadi korban dari sistem tersebut (Mosse 1996). Terdapat lima bentuk ketidakadilan gender, yaitu:

1. Marginalisasi, yaitu pemiskinan ekonomi terhadap suatu kelompok gender. Dilihat dari segi sumbernya, keadilan bisa berasal dari kebijakan pemerintah, keyakinan keagamaan, tradisi bahkan asumsi ilmu pengetahuan. Marginalisasi juga terjadi karena adanya diskriminasi terhadap pembagian kerja secara gender.

2. Subordinasi, yaitu seperti menempatkan suatu kelompok gender pada posisi lebih rendah. Misalnya, pandangan bahwa perempuan itu emosional, maka ia dianggap tidak bisa memimpin. Bentuk subordinasi bermacammacam, berbeda-bedadari tempat ke tempat dan dari waktu ke waktu.

3. Stereotip, yaitu pelabelan negatif terhadap suatu kelompok gender. Misal label bahwa wanita itu bersolek dalam rangka memancing lawan jenis.

4. Kekerasan, yaitu suatu serangan terhadap fisik maupun mental psikologis seseorang. Sumber kekerasan terhadap manusia bermacam-macam, baik yang dilakukan dalam rumah tangga sampai pada tingkat negara.

5. Beban kerja ganda. Karena adaya anggapan bahwa kaum wanita bersifat memelihara dan rajin, serta tidak akan menjadi kepala rumah tangga, akibatnya semua pekerjaan domestik menjadi tanggung jawab wanita. Di kalangan keluarga miskin, beban ganda terjadi, selain harus bekerja domestik, mereka harus membantu mencari nafkah.

\section{Upaya Adaptasi dan Mitigasi Perubahan Iklim}

Menurut BMKG (Badan Meteorologi, Klimatologi, dan Geofsika) diacu oleh UNDP (2007), perubahan iklim mengakibatkan mundurnya awal musim hujan sehingga berdampak pada mundurnya awal musim tanam dan lamanya musim paceklik. Di sisi lain, beberapa wilayah Indonesia akan mengalami curah hujan di atas normal. Untuk wilayah yang mengalami 
curah hujan di atas normal akan dihadapkan pada terjadinya bencana banjir, tanah longsor, krisis air bersih, gagal panen, dan meningkatnya penyebaran penyakit demam berdarah

Mengantisipasi dampak perubahan iklim perlu dilakukan upaya mitigasi dan adaptasi. Menurut Peraturan Kementerian Lingkungan Hidup dan Kehutanan Republik Indonesia (KLHK 2016), adaptasi perubahan iklim adalah upaya yang dilakukan untuk meningkatkan kemampuan dalam menyesuaikan diri terhadap dampak perubahan iklim, termasuk keragaman iklim dan kejadian iklim ekstrim sehingga potensi kerusakan akibat perubahan iklim berkurang, peluang yang ditimbulkan oleh perubahan iklim dapat dimanfaatkan, dan konsekuensi yang timbul akibat perubahan iklim dapat diatasi. Mitigasi Perubahan Iklim adalah serangkaian kegiatan preventif yang dilakukan dalam upaya menurunkan tingkat emisi gas rumah kaca sebagai bentuk upaya penanggulangan dampak perubahan iklim.

Kementerian Lingkungan Hidup dan Kehutanan dalam Peraturan Menteri Lingkungan Hidup dan Kehutanan Republik Indonesia yang sudah direvisi tahun 2016 menetapkan Program Kampung Iklim sebagai program berlingkup nasional yang dikelola oleh Kementerian Lingkungan Hidup dan Kehutanan dalam rangka meningkatkan keterlibatan masyarakat dan pemangku kepentingan lain untuk melakukan penguatan kapasitas adaptasi dengan melakukan upada adptasi dan mitigasi perubahan iklim.

Pelaksanaan Program Kampung Iklim mengacu pada Peraturan Menteri Lingkungan Hidup Nomor 19 Tahun 2012 tentang Program Kampung Iklim, yang kemudian diperbaharui pada Peraturan Menteri Lingkungan Hidup dan Kehutanan Republik Indonesia Nomor P.84/MENLHKSETJEN/KUM.1/11/2016, dan kembali ditindaklanjuti dengan dikeluarkannya Peraturan Dirjen Pengendalian Perubahan Iklim Nomor: P.1/PPI/SET/KUM.1/2/2017 tentang Pedoman Pelaksanaan Program Kampung Iklim. Kampung Iklim adalah lokasi yang berada di wilayah administratif paling rendah setingkat rukun warga atau dusun dan paling tinggi setingkat kelurahan atau desa, atau wilayah yang masyarakatnya telah melakukan upaya adaptasi dan mitigasi perubahan iklim secara berkesinambungan (KLHK 2016).

\section{Gender dan Peubahan Iklim}

Menurut Forum Masyarakat Sipil untuk Keadilan Iklim (2011), dampak perubahan iklim terasa begitu nyata bagi warga tanpa informasi yang mencukupi, kemampuan bertahan hidup yang lemah, khususnya perempuan. Pernyataan ini kemudian didukung oleh KPPPA (2015) yang mengacu pada penelitian dari London School of Economics menyatakan bahwa pada setiap terjadi bencana, korban perempuan tercatat empat kali lebih tinggi daripada korban lakilaki. Hal tersebut terjadi berhubungan dengan perbedaan hak ekonomi dan sosial antar gender.

KPPPA (2015) juga menambahkan bahwa adaptasi perubahan iklim tidak netral gender karena perempuan dan laki-laki memiliki kapasitas, peran, dan berkontribusi terhadap adaptasi perubahan iklim secara berbeda. Perempuan dan laki-laki juga memiliki perbedaan kebutuhan (strategi maupun praktis) dan minat dalam upaya-upaya beradaptasi. Strategi dan tidakan adaptasi, di sisi lain, dapat memiliki dampak berbeda terhadap perempuan dan laki-laki, dan berpotensi meningkatkan atau mengurangi bias gender yang telah ada.

Akibat adanya peran sosial yang bias gender, pada akhirnya berdampak pada minimnya akses kelompok perempuan terhadap sumber daya, baik sumber daya alam, sumber daya ekonomi, maupun sumber daya politik. Hal ini kemudian menyebabkan kapasitas adaptasi yang dimiliki oleh kelompok perempuan untuk menghadapi perubahan iklim cukup minim. Akibatnya, pada saat terpapar dampak perubahan iklim, perempuan menjadi kelompok yang memiliki beban ganda, perempuan lebih banyak menjadi korban, dan perempuan menjadi kelompok yang lebih rentan (KPPPA 2011).

\section{Karakteristik Rumah Tangga Pertanian}

Menurut BPS (2016) rumah tangga adalah seorang atau sekelompok orang yang mendiami sebagian atau seluruh bangunan fisik, dan biasanya tinggal bersama serta makan dari satu dapur. Setiap rumah tangga memiliki karakteristitik sosial ekonomi yang berbeda. Yuwono (2012) dalam analisis gender dalam program pengembangan usaha agribisnis pedesaan (PUAP) mengungkapkan bahwa karakteristik rumah tangga yaitu:

1. Umur. Berdasarkan hasil penelitian yang dilakukan oleh Prastiwi (2012) umur memiliki hubungan yang signifikan terhadap tingkat kesetaraan gender. Menurut Havighurst (1950) diacu Mugniesyah (2009), tingkatan umur dapat 
digolongkan berdasarkan tigkat perkembangannya yang terbagi menjadi tiga yakni dewasa awal (18-30 tahun), dewasa menengah (31-50 tahun), dan tua ( $>51$ tahun).

2. Tingkat pendidikan. Berdasarkan UU RI No 20 tahun 2003 Pasal 1 pendidikan adalah usaha sadar dan terencana untuk mewujudkan suasana belajar dan proses pembelajaran agar peserta didik secara aktif mengembangkan potensi dirinya untuk memiliki kekuatan spiritual keagamaan, pengendalian diri, kecerdasan, serta keterampilan yang diperlukan dirinya, masyarakat, Bangsa dan Negara.

3. Luas lahan. Fitria (2015) menyatakan bahwa Lahan adalah faktor produksi paling penting bagi petani, semakin luas lahan yang dikuasainya, maka produktivitasnya akan semakin tinggi. Yuwono (2012) menyatakan terdapat hubungan yang nyata antara luas lahan kering yang dimiliki petani dengan tingkat akses dari komponen PUAP perspektif gender.

4. Tingkat pendapatan. Tingkat pendapatan adalah salah satu indikator kesejahteraan petani (Departemen Pertanian 2008). Fitria (2015) menyatakan bahwa karakteristik sosial ekonomi rumah tangga yaitu tingkat pendapatan memiliki hubungan positif terhadap tingkat akses terhadap sumber daya pangan.

\section{Kerangka Pemikiran}

Rumah tangga merupakan subjek utama penelitian ini. Terdapat tiga konsep yang dianalisis dalam penelitian ini, yaitu karakteristik rumah tangga (umur, tingkat pendidikan, luas lahan pertanian, dan tingkat pendapatan), peran gender (peran reproduktif, peran produktif, dan peran sosialkemasyarakatan) dan tingkat kesetaraan gender (akses, kontrol, partisipasi dan manfaat) dalam upaya adaptasi dan mitigasi perubahan iklim.

Antar-variabel diasumsikan memiliki hubungan yang signifikan. Variabel umur, tingkat pendidikan, luas lahan pertanian dan tingkat pendapatan rumah tangga diasumsikan memiliki hubungan signifikan terhadap pembagian peran reproduktif, peran produktif, dan peran sosial-kemasyarakatan dalam rumah tangga pertanian. Kemudian variabel dari kedua konsep tersebut, yaitu umur, tingkat pendidikan, luas lahan pertanian dan tingkat pendapatan, serta pembagian peran reproduktif, peran produktif, dan peran sosial kemasyarakatan dalam rumah tangga pertanian memiliki hubungan signifikan dengan tingkat kesetaraan akses, kontrol, partisipasi, dan manfaat dari kegiatan upaya adaptasi dan mitigasi perubahan iklim berdasarkan Laporan Verifikasi Program Kampung Iklim Desa Gekbrong yang dilakukan Kementerian Lingkungan Hidup dan

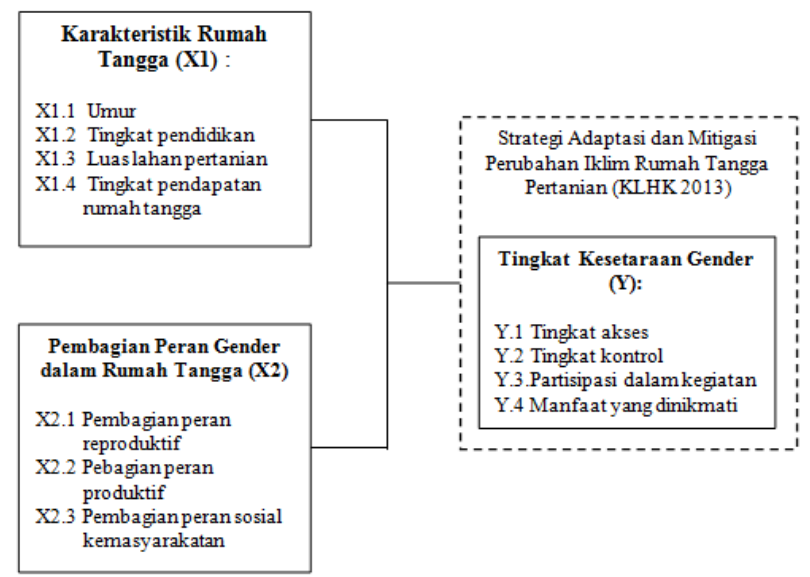

Kehutanan pada tahun 2013.

Gambar 2 Kerangka pikir

: Berhubungan

\section{METODE PENELITIAN}

Penelitian ini merupakan penelitian yang menggunakan metode kuantitatif yang didukung dengan data kualitatif. Metode kuantitatif dilakukan dengan pendekatan survei menggunakan kuesioner sebagai instrumen utama penelitian. Sementara itu, data kualitatif merupakan data hasil dari wawancara mendalam, observasi lapang, dan penelusuran dokumen.

Penelitian dilaksanakan mulai dari bulan Maret sampai dengan November 2017. Lokasi penelitian yaitu Desa Gekbrong, Kecamatan Gekbrong, Kabupaten Cianjur, Provinsi Jawa Barat. Lokasi tersebut dipilih secara purposive. Dipilihnya lokasi tersebut dengan pertimbangan:

1. Desa Gekbrong merupakan satu-satunya desa di Jawa Barat yang mendapatkan trophy dan sertifikat desa percontohan Program Kampung Iklim oleh Kementerian Lingkungan Hidup dan Kehutanan pada tahun 2013;

2. Desa Gekbrong mengalami beberapa bencana alam, salah satunya banjir pada tahun 2012 hingga memakan korban jiwa;

3. PT. Tirta Investama Cianjur (milik AQUA Group) melakukan CSR berupa pendampingan ecofarming yang tahan iklim pada beberapa 
anggota kelompok tani di Kampung Tabrik, Desa Gekbrong.

Sumber data dalam penelitian ini adalah responden dan informan. Responden merupakan individu yang dapat memberikan keterangan atau informasi mengenai dirinya sendiri berkaitan dengan penelitian yang dilakukan. Unit analisa penelitian ini yaitu rumah tangga pertanian. Populasi dalam penelitian ini adalah seluruh rumah tangga pertanian hortikultura di Desa Gekbrong. Setelah itu, ditentukan sampel penelitian yang berjumlah 40 rumah tangga responden yang diambil secara simple random sampling. Hal tersebut dilakukan dengan cara memilih kampung yang memiliki petani hortikultura terbanyak, kemudian diambil 40 rumah tangga dengan acak. Responden diwawancarai sesuai dengan kuisioner.

Informan merupakan orang yang mampu memberikan keterangan yang sesuai dengan informasi yang dibutuhkan. Pemilihan informan dilakukan secara purposive sesuai dengan rekomendasi dari warga dan jumlahnya tidak ditentukan. Orang-orang yang dijadikan sebagai informan dalam penelitian ini adalah kepala desa, ketua RW, ketua kelompok tani, serta masingmasing petani responden.

Data dalam penelitian ini meliputi data primer dan data sekunder. Pada penelitian ini, data primer diperoleh langsung dari responden dan informan melalui survei, observasi serta wawancara; data sekunder diperoleh dari dokumen-dokumen tertulis atau arsip di kantor kepala desa, buku, internet, data dari Badan Pusat Statistik (BPS), jurnal-jurnal penelitian, pedoman teknis Program Kampung Iklim serta pedoman umum adaptasi perubahan iklim dalam pertanian oleh Kementerian Pertanian, yang berkaitan dengan penelitian ini.

Data primer kuantitatif dikumpulkan melalui wawancara terstruktur kepada 40 rumah tangga responden. Data primer kualitatif dikumpulkan melalui wawancara mendalam (indepth interview) kepada sejumlah informan.

Data yang diperoleh melalui kuesioner diolah dengan menggunakan Microsoft Excel 2016 Kemudian SPSS for windows 21 digunakan untuk membantu dalam uji statitistik dengan menggunakan Uji Korelasi Rank Spearman untuk mengukur hubungan antar variabel. Tanda bintang $(*)$ yang terdapat pada nilai korelasi koefisien menunjukkan signifikansi atau hubungan antar variabel.
Interpretasi lebih lanjut mengenai kekuatan hubungan antar dua variabel, menggunakan pendapat dari Nugroho (2005) dengan kriteria berdasarkan nilai koefisien korelasi berikut:
a. $0 \quad$ : Tidak ada korelasi
b. $0-0,20$ : Korelasi sangat lemah
c. $0,21-0,30$ : Korelasi lemah
d. $0,31-0,70$ : Korelasi kuat
e. $0,71-0,90$ : Korelasi sangat kuat
f. $0,91-0,99$ : Korelasi sangat kuat sekali
g. 1 : Korelasi sempurna

\section{HASIL DAN PEMBAHASAN}

\section{Karakteristik Rumah Tangga Pertanian}

Umur yang digunakan dalam penelitian rumah tangga pertanian yaitu umur petani utama dalam rumah tangga pertanian responden (ST2013 oleh BPS 2013). Seluruh petani utama dalam rumah tangga pertanian pada penelitian ini adalah suami. Tingkat pendidikan yang digunakan dalam penelitian rumah tangga pertanian yaitu tingkat pendidikan kepala rumah tangga pertanian (Kementerian Pertanian 2014). Rentang nilai pengkategorian luas lahan dan pendapatan rumah tangga pertanian dalam penelitian ini menggunakan rata-rata dan standar deviasi. Persentase rumah tangga pertanian di Desa Gekbrong berdasarkan karakteristik rumah tangga ditampilkan dalam Tabel 2.

Tabel 2 Jumlah dan persentase rumah tangga pertanian berdasarkan karakteristik rumah tangga, Desa Gekbrong, tahun 2017

\begin{tabular}{|c|c|c|}
\hline \multirow{2}{*}{ Variabel } & \multicolumn{2}{|c|}{ Jumlah } \\
\hline & $\mathrm{n}$ & $\%$ \\
\hline \multicolumn{3}{|l|}{ Umur } \\
\hline Dewasa Awal (18- & 3 & 7.5 \\
\hline tahun) & 28 & 70 \\
\hline Tua $(>50$ & 9 & 22.5 \\
\hline \multicolumn{3}{|l|}{ Pendidikan } \\
\hline $\begin{array}{l}\text { Rendah (Tidak Sekolah atau Tidak } \\
\text { Tamat SD) }\end{array}$ & 6 & 15 \\
\hline Sedang (Tamat SD) & 27 & 67.5 \\
\hline Tinggi (Tamat SMP dan c & 7 & 17.5 \\
\hline \multicolumn{3}{|l|}{ Luas Lahan Pertanian } \\
\hline Sempit $\left(<1000 \mathrm{~m}^{2}\right)$ & 10 & 25 \\
\hline $\left.0 m^{2}-5000 m^{2}\right)$ & 24 & 60 \\
\hline Luas $\left(>5000 \mathrm{~m}^{2}\right)$ & 6 & 15 \\
\hline \multicolumn{3}{|l|}{ Pendapatan } \\
\hline Rendal & 13 & 32.5 \\
\hline Sedang (Rp 2.000.000/bulan - Rp & 21 & 52.5 \\
\hline Tinggi (> Rp 8.000.000/bulan) & 6 & 15 \\
\hline
\end{tabular}


Total

$40 \quad 100$

Sumber: Data primer

Berdasarkan Tabel 2, dari 40 rumah tangga pertanian di Desa Gekbrong, mayoritas rumah tangga pertanian memiliki petani utama dengan kategori usia sedang yaitu antara 31 hingga 50 tahun. Mayoritas rumah tangga pertanian memiliki kepala rumah tangga pada tingkat pendidikan sedang yaitu tamat SD. Kepemilikan luas lahan pada mayoritas rumah tangga pertanian berada di tingkat sedang yaitu antara $1000 \mathrm{~m}^{2}$ hingga $5000 \mathrm{~m}^{2}$. Sedangkat tingkat pendapatan pada mayoritas rumah tangga pertanian berada di kategori tingkat pendapatan sedang yaitu Rp2.000.000 hingga Rp8.000.000 dalam sebulan.

\section{Pembagian Peran Gender dalam Rumah Tangga}

Peran gender laki-laki dan perempuan diklasifikasikan dalam tiga peran pokok yaitu peran reproduktif, peran produktif, dan peran sosialkemasyarakatan. Pembagian kerja atau pembagian peran gender merupakan peran yang diciptakan masyarakat bagi perempuan dan laki-laki. Istilah peran mengacu pada norma berperilaku yang berlaku untuk laki-laki dan perempuan dalam suatu struktur sosial (Hubeis 2010).

Pembagian peran reproduktif dominan dilakukan oleh hanya perempuan dalam rumah tangga pertanian, seperti kegiatan belanja kebutuhan seharihari, memasak, menyapu, mengepel, mencuci pakaian, mencuci piring, menyetrika, mendampingi anak bermain, mendampingi anak belajar, mengantar anak sekolah, dan merawat anak ketika sakit. Kegiatan reproduktif yang dominan dilakukan oleh hanya laki-laki dalam rumah tangga pertanian, yaitu mengatur keuangan rumah tangga dan memperbaiki perkakas rumah tangga. Kegiatan reproduktif yang dominan dilakukan bersama antara laki-laki dan perempuan dalam rumah tangga pertanian yaitu mengantar anak berobat ketika sakit.

Pembagian peran produktif dominan dilakukan oleh hanya laki-laki dalam rumah tangga pertanian, seperti pada jenis kegiatan pengelolaan lahan, penyiapan bibit, membuat bumbunan tanah, memasang mulsa, menali tanaman, memberikan obat, memberikan pupuk, menjual hasil panen, dan mengolah limbah pertanian. Kegiatan produktif yang dilakukan bersama antara laki-laki dan perempuan dalam rumah tangga pertanian yaitu menebarkan bibit, menyiram, memanem dan melakukan kontrol pada pekerja pertanian. Tidak ada kegiatan produktif yang didominasi dilakukan oleh hanya perempuan dalam rumah tangga pertanian. Meski begitu, terdapat rumah tangga pertanian dengan persentase cukup besar yang melakukan menali tanaman dan membersihkan rumput liar oleh hanya perempuan.

Pembagian peran sosial-kemasyarakatan banyak dilakukan bersama antara perempuan dan laki-laki dalam rumah tangga, seperti jenis kegiatan pengajian, upacara kematian dan pernikahan. Kegiatan sosial kemasyarakatan yang dominan dilakukan oleh hanya perempuan dalam rumah tangga pertanian yaitu acara kelahiran. Kegiatan yang dominan dilakukan oleh hanya laki-laki dalam rumah tangga yaitu kerja bakti dan musyawarah desa, dan tidak ada rumah tangga yang mengikutsertakan perempuan dalam musyawarah desa.

Tabel 3. Jumlah dan persentase rumah tangga pertanian berdasarkan pembagian peran gender, Desa Gekbrong, 2017

\begin{tabular}{lrr}
\hline & \multicolumn{2}{c}{ Vumlah } \\
\cline { 2 - 3 } & $\mathrm{n}$ & $\%$ \\
\hline Pembagian Peran Reproduktif & & \\
Bias & 37 & 92.5 \\
Sedang & 2 & 5 \\
Setara & 1 & 2.5 \\
\hline Pembagian Peran Produktif & \multicolumn{2}{c}{} \\
Bias & 24 & 60 \\
Sedang & 12 & 30 \\
Setara & 4 & 10 \\
\hline Pembagian Peran Sosial-Kemasyarakatan & \\
Bias & 6 & 15 \\
Sedang & 30 & 75 \\
Setara & 4 & 10 \\
\hline Total & 40 & 100 \\
\hline
\end{tabular}

Secara keseluruhan, pembagian peran dalam rumah tangga pertanian perspektif kesetaraan gender ditampilkan pada Tabel 3. Berdasarkan Tabel 3, rumah tangga pertanian di Desa Gekbrong bias gender dalam pembagian peran reproduktif dan produktif.

\section{Kesetaraan Gender dalam Upaya Adaptasi dan Mitigasi Perubahan Iklim}

Pada upaya adaptasi dan mitigasi perubahan iklim, akses terhadap penyuluhan \& pelatihan dan kontrol terhadap perlakuan pada tanaman usaha tani, seperti obat tanaman, jenis komoditas yang ditanam, penentuan waktu tanam, pupuk, serta perlakuan hasil 
tani didominasi laki-laki. Sumberdaya lainnya dapat diakses dan dikontrol bersama antara laki-laki dan perempuan. Jenis kegiatan dengan partisipasi dominan oleh laki-laki yaitu kegiatan pada usaha tani dengan kerja fisik seperti pembuatan penampungan air hujan (PAH), biopori, meninggikan lahan pengomposan limbah dan membuka lahan. Sedangkan jenis kegiatan dengan partisipasi dominan oleh perempuan yaitu pemanfaatan kembail air Rumah Tangga dan melakukan 3M pada sarang nyamuk. Manfaat adaptasi dan mitigasi perubahan iklim dominasi diterima oleh laki-laki. Secara keseluruhan, tingkat kesetaraan gender berdasarkan akses, kontrol, partisipasi dan manfaat dalam upaya adaptasi dan mitigasi perubahan iklim dapat dilihat pada Tabel 4.

Tabel 4. Jumlah dan persentase rumah tangga pertanian berdasarkan tingkat kesetaraan gender, Desa Gekbrong, 2017

\begin{tabular}{lrr}
\hline & \multirow{2}{*}{ Variabel } & \multicolumn{2}{c}{ Jumlah } \\
\cline { 2 - 3 } & $\mathrm{n}$ & $\%$ \\
\hline Akses & 2 & 5 \\
Rendah & 27 & 67.5 \\
Sedang & 11 & 27.5 \\
Tinggi & & \\
\hline Kontrol & 11 & 27.5 \\
Rendah & 18 & 45 \\
Sedang & 11 & 27.5 \\
Tinggi & & \\
\hline Partisipasi & 6 & 15 \\
Rendah & 30 & 75 \\
Sedang & 4 & 10 \\
Tinggi & & \\
\hline Manfaat & 10 & 25 \\
Rendah & 18 & 45 \\
Sedang & 12 & 30 \\
Tinggi & 40 & 100 \\
\hline Total & & \\
\hline
\end{tabular}

Berdasarkan Tabel 4, tingkat kesetaraan akses, kontrol, partisipasi dan manfaat dalam upaya adaptasi dan mtitigasi perubahan iklim oleh rumah tangga pertanian di Desa Gekbrong secara umum berada pada tingkat sedang, yang berarti baik perempuan maupun laki-laki dapat menguasai, berpartisipasi dan menerima manfaat meski belum benar-benar setara gender.

\section{Hubungan Karakteristik Rumah Tangga dengan Pembagian Peran Gender dalam Rumah Tangga Pertanian}

Hasil uji korelasi Rank Spearman antar-variabel dari karakteristik rumah tangga pertanian dengan kesetaraan pembagian peran gender dalam rumah tangga pertanian dapat dilihat pada Tabel 5.

Tabel 5. Koefisien korelasi antara karakteristik rumah tangga dengan pembagian peran gender, Desa Gekbrong, 2017

\begin{tabular}{|c|c|c|c|}
\hline \multirow[b]{2}{*}{$\begin{array}{c}\text { Karakteristik Rumah } \\
\text { Tangga }\end{array}$} & \multicolumn{3}{|c|}{ Koefisien Korelasi } \\
\hline & $\begin{array}{c}\mathrm{Re}- \\
\text { produktif }\end{array}$ & $\begin{array}{l}\text { Pro- } \\
\text { duktif }\end{array}$ & Sosial \\
\hline Umur & -0.092 & -0.248 & 0.117 \\
\hline Tingkat Pendidikan & -0.187 & 0.082 & 0.268 \\
\hline $\begin{array}{l}\text { Luas Lahan } \\
\text { Pertanian }\end{array}$ & -0.056 & -0.323 & 0.094 \\
\hline Tingkat Pendapatan & 0.095 & -0.298 & 0.034 \\
\hline
\end{tabular}

Sumber: Data Primer

Berdasarkan Tabel 5, terdapat hubungan yang signifikan antara luas kepemilikan lahan pertanian dengan pembagian peran produktif pada rumah tangga pertanian. Hubungan bersifat negatif, yang artinya semakin luas lahan pertanian yang dimiliki, semakin bias gender dalam pembagian peran produktif di rumah tangga pertanian.

Pada kategori umur dan tingkat pendidikan, hasil penelitian ini tidak sejalan dengan pendapat Fauziah, Mulyana dan Raharjo (2015), yang menganggap bahwa umur dan tingkat pendidikan berhubungan linier dengan pengetahuan tetang pembagian peran dan kesetaraan gender dalam rumah tangga. Pada kategori tingkat pendapatan, hasil penelitian ini sejalan dengan uji korelasi yang dilakukan Puspitawati et al (2010), yaitu peran gender domestik (reproduktif) memiliki korelasi lemah dengan pendapatan total, dan peran gender publik (sosial) hampir tidak memiliki korelasi dengan pendapatan total.

\section{Hubungan Karakteristik dan Pembagian Peran Gender dalam Rumah Tangga dengan Tingkat Kesetaraan Gender dalam Upaya Adaptasi dan Mitigasi Perubahan Iklim}

Hasil uji korelasi Rank Spearman antara karakteristik rumah tangga dan pembagian peran gender dengan tingkat kesetaraan gender dalam upaya adaptasi dan mitigasi perubahan iklim ditampilkan dalam Tabel 6 .

Berdasarkan Tabel 6, dari karakteristik rumah tangga dengan tingkat kesetaraan gender dalam upaya 
adaptasi dan mitigasi perubahan iklim, terdapat hubungan signifikan antara: 1) umur dan tingkat pendidikan dengan tingkat kesetaraan akses; 2) umur dengan tingkat kesetaraan kontrol; 3) umur dan tingkat pendidikan dengan tingkat kesetaraan partisipasi; dan 4) umur, tingkat pendidikan, luas lahan pertanian dan tingkat pendapatan dengan tingkat kesetaraan manfaat dalam upaya adaptasi dan mitigasi perubahan iklim.

Sedangkan antar-variabel dari pembagian peran gender dalam rumah tangga dengan tingkat kesetaraan gender dalam upaya adaptasi dan mitigasi perubahan iklim, terdapat hubungan signifikan antara pembagian peran produktif dengan tingkat kesetaraan akses, kontrol, partisipasi dan manfaat dalam upaya adaptasi dan mitigasi perubahan iklim.

Tabel 6 Koefisien korelasi antara karakteristik dan pembagian peran gender dengan tingkat kesetaraan gender, Desa Gekbrong, 2017

\begin{tabular}{lrrrr}
\hline \multirow{2}{*}{ Variabel } & \multicolumn{4}{c}{ Koefisien Korelasi } \\
\cline { 2 - 5 } & Akses & $\begin{array}{r}\text { Kon- } \\
\text { trol }\end{array}$ & $\begin{array}{r}\text { Partsi- } \\
\text { pasi }\end{array}$ & $\begin{array}{r}\text { Manfa } \\
\text { Umut }\end{array}$ \\
\hline Umur & $\mathbf{- 0 . 5 5 8}$ & $\mathbf{- 0 . 4 3 8}$ & $\mathbf{- 0 . 4 7 4}$ & $\mathbf{- 0 . 5 3 0}$ \\
$\begin{array}{l}\text { Tingkat } \\
\text { Pendidikan }\end{array}$ & $\mathbf{0 . 4 0 1}$ & 0.298 & $\mathbf{0 . 3 2 5}$ & $\mathbf{0 . 3 5 8}$ \\
$\begin{array}{l}\text { Luas Lahan } \\
\text { Pertanian }\end{array}$ & -0.223 & -0.277 & -0.266 & $\mathbf{- 0 . 3 3 4}$ \\
$\begin{array}{l}\text { Tingkat } \\
\text { Pendapatan }\end{array}$ & -0.234 & -0.307 & -0.278 & $\mathbf{- 0 . 3 4 9}$ \\
$\begin{array}{l}\text { Peran } \\
\text { Reproduktif }\end{array}$ & 0.050 & -0.01 & -0.047 & 0.103 \\
$\begin{array}{l}\text { Peran } \\
\text { Produktif }\end{array}$ & $\mathbf{0 . 5 1 1}$ & $\mathbf{0 . 5 9 8}$ & $\mathbf{0 . 3 8 6}$ & $\mathbf{0 . 6 0 7}$ \\
Peran Sosial & 0.127 & 0.069 & 0.093 & 0.069 \\
\hline Sumber: Data Primer & & & &
\end{tabular}

\section{SIMPULAN DAN SARAN}

\section{Simpulan}

1. Mayoritas rumah tangga pertanian hortikultura di Desa Gekbrong memiliki petani utama dalam rumah tangga usia dewasa menengah yakni 31 sampai 50 tahun dengan tingkat pendidikan kategori sedang yaitu tamat SD. Tingkat kepemilikan lahan pertanian rumah tangga responden dominan berada pada luas lahan sedang yaitu antara $1000 \mathrm{~m}^{2}$ hingga $5000 \mathrm{~m}^{2}$ dan tingkat pendapatan sedang yaitu antara Rp2.000.000 - Rp8.000.000 dalam sebulan.
Pembagian peran reproduktif rumah tangga pertanian dominan hanya dilakukan perempuan, sedangkan pembagian peran produktif lebih beragam namun laki-laki masih lebih banyak mengambil peran. Peran sosialkemasyarakatan dilakukan bersama oleh lakilaki dan perempuan. Terdapat hubungan signifikan antara luas lahan pertanian yang dimiliki dengan pembagian peran produktif dalam rumah tangga pertanian.

2. Akses dan kontrol terhadap sumber daya kegiatan adaptasi dan mitigasi perubahan iklim dalam hal penyuluhan dan pelatihan masih didominasi hanya oleh laki-laki dalam rumah tangga. Kontrol sumber daya yang didapat bersama hanya pada penggunaan alat pertanian dan penggunaan air bersih. Partisipasi dalam kegiatan juga dominasi dilakukan hanya oleh laki-laki dalam rumah tangga. Manfaat kegiatan upaya adaptasi dan mitigasi perubahan iklim dominan dirasakan bersama, kecuali pengetahuan dan komoditas perubahan iklim yang didominasi hanya oleh laki-laki dalam rumah tangga.

3. Terdapat hubungan signifikan antara: 1) umur dan tingkat pendidikan dengan tingkat kesetaraan akses; 2) umur dengan tingkat kesetaraan kontrol; 3) umur dan tingkat pendidikan dengan tingkat kesetaraan partisipasi; dan 4) umur, tingkat pendidikan, luas lahan pertanian dan tingkat pendapatan dengan tingkat kesetaraan manfaat; 5) pembagian peran produktif dengan tingkat kesetaraan akses, kontrol, partisipasi dan manfaat dalam upaya adaptasi dan mitigasi perubahan iklim.

\section{Saran}

Terdapat beberapa saran yang bisa dijadikan masukan sebagai bahan pertimbangan adalah sebagai berikut:

1. Bagi akademisi, sebaiknya dilakukan penelitian lebih lanjut yang mengintegrasikan pembagian peranan produktif, reproduktif dan sosial berdasarkan spesifik curahan waktu lebih mendalam dan dilakukan analisis lanjutan berupa hubungan antara tingkat kesetaraan gender dengan tingkat kerentanan rumah tangga pertanian terhadap perubahan iklim. Sehingga signifikansi dari peran gender terhadap perubahan iklim dapat diketahui lebih dalam. 
2. Bagi masyarakat, kesetaraan gender tidak hanya diterapkan dalam proyek atau program pembangunan, namun juga pada pembagian peran gender dalam rumah tangga. Hal tersebut diharapkan agar tidak terjadi ketidakadilan gender dalam rumah tangga, seperti marginalisasi dan beban kerja ganda.

3. Bagi pemerintah, terutama dibawah naungan Kementerian Lingkungan Hidup dan Kehutanan, untuk membuat program yang memperhatikan pengarusutamakan gender dalam bidang adaptasi dan mitigasi perubahan iklim, agar program yang ada dapat memenuhi kebutuhan baik laki-laki maupun perempuan dalam menghadapi perubahan iklim. Sehingga mengurangi isu ketidakadilan gender yang disebabkan oleh kegiatan upaya adaptasi dan mitigasi perubahan iklim.

\section{DAFTAR PUSTAKA}

[BAPPENAS]. Badan Perencanaan Pembangunan Nasional. 2007. Gender Analysis Pathway (GAP), Alat Analisis Gender untuk Perencanaan Pembangunan. Jakarta (ID): Bappenas dan KPPPA.

[BPPP]. Badan Penelitian dan Pengembangan Pertanian. 2011. Pedoman Umum Adaptasi Perubahan Iklim Sektor Pertanian. Tersedia pada: http://www.pertanian.go.id/dpi/downlot.php?file = pedum-adaptasi.pdf

[BPS]. Badan Pusat Statistik. 2013. Laporan Hasil Sensus Pertanian 2013. [internet]. [diunduh 10 Agustus 2017]. Tersedia pada: https://st2013.bps.go.id/st2013esya/booklet/at00 $\underline{00 . p d f}$

2016. Berita Resmi Statistik Provinsi jawa Barat. [internet]. [diunduh 15 Agustus 2017]. Tersedia pada: https://jabar.bps.go.id/

[CSF]. Forum Masyarakat Sipil untuk Keadilan Iklim. 2011. Keadilan Gender dalam Keadilan Iklim. [internet]. Tersedia pada: http://www.lifemosaic.net/images/uploads/7Perubahan-Iklim-dan-gender-indo01.pdf

Fakih M. 1999. Analisis Gender \& Transformasi Sosial. Yogyakarta (ID): Pustaka Pelajar.

Fauziah R, Mulyana N, Raharjo ST. 2015. Pengetahuan msyarakat desa tentang kesetaraan gender. Prosiding KS: Riset \& PKM. Hal 147-300. Bandung (ID): Universitas Padjajaran.

Findeis JL, Swaminathan H. 2002. Multiple Job Holding Among Us Farm Women. [Paper] Annual meeting of The American Agricultural Economic Association.

Fitria N. 2015. Peran Gender dalam Diversifikasi Konsumsi Pangan Mendayagunakan Pangan
Pokok Lokal. [skripsi]. Bogor (ID): Institut Pertanian Bogor. [Internet]. [diunduh pada 1 Agustus 2016]. Tersedia pada: http://repository.ipb.ac.id/handle/123456789/80 708

Hubeis AVS . 2010. Pemberdayaan Perempuan dari Masa ke Masa. Bogor (ID): IPB Press.

Irianto G. 2004 Apr 5. Pengarusutamaan jender untuk mitigasi dan adaptasi perubahan iklim ekstrem. Kompas. [internet]. Tersedia pada: www.litbang.pertanian.go.id/artikel/one/264/

Kementerian Pertanian. 2014. Analisis Data Kesejahteraan Petani Tahun 2014. [internet]. [diunduh pada 7 Mei 2017]. Tersedia pada: pusdatin.setjen.pertanian.go.id/.../file/Analisis_ Kestan 2014.pdf

[KLHK]. Kementerian Lingkungan Hidup dan Kehutanan. 2013. Laporan Verifikasi Program kampung Iklim Desa Gekbrong. [internet]. [diunduh pada 7 Mei 2017]. Tersedia pada: http://dlh.jabarprov.go.id/index.php/layanan/dok umen/kegiatan/proklim/61-laporan-hasilverifikasi-gekbrong/file

2016. Peraturan Menteri Lingkungan Hidup dan Kehutanan Republik Indonesia Nomor P.84 Tahun 2016 tentang Program Kampung Iklim.

[KPPPA]. Kementerian Pemberdayaan Perempuan dan Perlindungan Anak. 2011. Gender dalam bencana alam dan adaptasi iklim. http://www.kemenpppa.go.id/lib/uploads/list/c3 b33-6.-gender-dalam-bencana-alam-danadaptasi-iklim.pdf

2015. Pembangunan Manusia Berbasis Gender 2015. Jakarta (ID) : Kementerian Pemberdayaan Perempuan dan Perlindungan Anak.

Kurniawati F. 2012. Pengetahuan dan adaptasi petani sayuran terhadap perubahan iklim. [Thesis]. Bandung (ID): Universitas Padjajaran.

Las I, Pramudia A, Runtunuwu E, Setyanto P. 2011. Antisipasi Perubahan Iklim dalam mengamankan Produksi Beras Nasional. Pengembangan Inovasi Pertanian 4(1).

Maulidah S, Santoso H, Subagyo H, Rifqiyah Q. 2012. Dampak perubahan iklim terhadap produksi dan pendapatan usahatani cabai rawit. Jurnal SEPA 8(2). Malang (ID): Universitas Brawijaya.

McRight AM. 2010. The effect of gender onclimate change knowledge and concern in American public. Popul Environ. Hal 66-87. Springer Science, Bussiness Media.

Mosse JC. 1996. Gender \& Pembangunan. Silawati H, penerjemah; Miftahudin M, editor. Yogyakarta (ID): Pustaka Pelajar. Terjemahan dari: Half The World, Half The Chance: An Introduction to Gender and Development.

Mugniesyah SSM, Fadhilah P. 2001. Analisis Gender dalam Pembangunan Pertanian (Aplikasi 
Gender Analysis Pathway-GAP). Jakarta (ID): CIDA, Bappenas, dan WSP II.

Mugniesyah SSM. 2007. Gender, Lingkungan, dan Pembangunan Berkelanjutan. Dalam Ekologi Manusia. Adiwibowo S, Editor. Bogor (ID): Fakultas Ekologi Manusia, Institut Pertanian Bogor.

Nugroho BA. 2005. Strategi Jitu Memilih Metode Statistik Penelitian dengan SPSS. Semarang (ID): Andi Offset.

Prastiwi D L, Sumarti T. 2012. Analisis Gender terhadap Tingkat Keberhasilan Pelaksanaan CSR bidang Pemberdayaan Ekonomi Lokal PT Holcim Indonesia Tbk. Jurnal Sosiologi Pedesaan [internet]. Diunduh pada: 26 Februari 2016. Tersedia pada: http://ejournal.skpm.ipb.ac.id/index.php/sodality /article/viewFile/240/25

Puspitawati H. 2008. Konsep, teori dan Analisis Gender. Jurnal Kesetaraan dan Keadilan Gender. [diunduh pada 12 Maret 2016]. tersedia pada http://ikk.fema.ipb.ac.id/v2/images/karyailmiah/ gender.pdf

. 2010. Presepsi peran gender terhadap pekerjaan domestik dan publik pada mahasiswa IPB. J. Studi Gender dan Anak. Hal 17-34. Purwokerto (ID): Pusat Studi Gender STAIN Purwokerto.

Puspitawati H, Herawati T, Sarma M. 2010. Analisis Gender Terhadap Strategi Koping dan Kesejahteraan Keluarga. Jurnal Penelitian dan Pengembangan Kesejahteraan Sosial. [internet]. [diunduh pada 6 Maret 2017]. tersedia pada

http://repository.ipb.ac.id/handle/123456789/64 899? show=full

[UNDP]. United Nations Development Programme. 2007. Sisi Lain Perubahan Iklim: Mengapa Indonesia Harus Beradaptasi untuk Melindungi Rakyat Miskinnya. Jakarta (ID): UNDP Indonesia Country Office.

Yuwono PA. 2012. Analisis Gender Pada Program Pengemabangan Usaha Agribisnis Perdesaan (PUAP). [skripsi]. Bogor (ID): Institut Pertanian Bogor. 